\title{
THE RELATIONSHIP BETWEEN OBESITY AND THE INCIDENCE OF INFERTILITY IN WOMEN
}

\section{Sandra Kryska}

\author{
Medical University of Silesia
}

Kryska S., (2014) The relationship between obesity and the incidence of infertility in women. Health Problems of Civilization 3 (8), p. 25-28

\begin{abstract}
Summary: A significant increase in the incidence of obesity, which has taken place in recent years caused that began to talk about the epidemic of obesity. This problem is characteristic of highly developed countries. Increasingly, also occurs in developing countries, including Polish. It occurs in all age groups and in almost all social groups. The disease is currently diagnosed in almost $25 \%$ of the Polish population. Increasingly, it is also diagnosed in young women and pregnant women. The literature increasingly emphasized the importance of obesity in disorders of insemination and proper implantation the fertilized ovum. For women who are overweight and obese, more often than women with normal body weight, comes to ovulation disorders and disturbances in the proper implantation of the fertilized ovum. These disorders result from the accumulation of adipose tissue and hormonal disorders resulting from them. Influence on fertility of women have not only expressed as their body weight BMI, but also as the content in the body fat and its distribution. The higher the fat content in the body making it harder and longer may be infertility treatment. It also noted the relationship between fat distribution and duration of treatment of infertility and its effect. More and more often also emphasized the importance of incorrect diets in young women as a factor in reducing fertility. This article is an attempt to collect and characterize the major causes of infertility seen in young women who are overweight or obese.
\end{abstract}

Key words: overweight, obesity, infertility, young women, BMI, adipose tissue

The literature increasingly emphasized the importance of obesity in disorders of insemination and proper implantation the fertilized ovum. These disorders result from the accumulation of adipose tissue and hormonal disorders resulting from them. More and more often also emphasized the importance of incorrect diets in young women as a factor in reducing fertility. This article is an attempt to collect and characterize the major causes of infertility seen in young women who are overweight or obese.

\section{Obesity epidemiology}

The most recent epidemiological data relating to the incidence of obesity show that fairly quickly it has become a significant problem for modern medical practice (Rich-Edwards et al. 2002). According to specialists, obesity has taken the size of the global epidemic which generates a significant threat to the health of people suffering from it (Bebelska et al. 2011).

The incidence of obesity occuring in the population of both women and men has escalated over the last decade (Jarvie, Ramsay 2010). The increase in the incidence of obesity occurence is noted in both higlhy developed and developing countries (Pupek-Musialik 2008). Excess weight and obesity are defined by means of the BMI (Body Mass Index) and now concern each age group regardless of gender or race.

In the year 2002, 1.4 million people were diagnosed with excess weight or obesity (BMI $>25 \mathrm{~kg} / \mathrm{m}^{2}$ ) around the world, whereas the problem of obesity (BMI $>30 \mathrm{~kg} / \mathrm{m}^{2}$ ) affected 365 million people (Wang, Beydoum 2007). Five years later (2007), more than 2 million people were diagnosed with excess weight or obesity. The number of obese people at this time reached 523 million (Kłosiewicz-Latoszek 2010). On a global scale, obesity occurs now at 7.7\% of men and $9.8 \%$ of women (Doak et al. 2012). According to experts' estimates by 2015 the number of obese population will have exceeded 700 million people worldwide (Kłosiewicz-Latoszek 2010).

The largest number of people with excess body weight is currently residing in the United States (Wang, Beydoum 2007). In 2010, the problem of overweight applied to $32 \%$ of the adult population of this country whereas further $34 \%$ of adults were obese. At the time, the percentage of children and adolescents suffering from

\section{Address for correspondence: Sandra Kryska, Medical University of Silesia, Plac Traugutta 2, 41-800 Zabrze,} e-mail: sandrakryska@vp.pl, phone: 608488185

Tables: 0, Figures: 0, References: 25, Full text PDF www.hpc.edu.pl Copyright (c) Pope John Paul II State School of Higher Education In Biała Podlaska, Sidorska 95/97, 21-500 Biała Podlaska Indexation: Index Copernicus, Database AGRO, ProQuest, Polish Ministry of Science and Higher Education. This is an open-access article distributed under the terms of the Creative Commons Attribution Non-commercial License (http://creativecommons.org/licenses/by-nc/3.0), which permits use, distribution, and reproduction in any medium, provided the original work is properly cited, the use is non-commercial and is otherwise in compliance with the license. 
obesity was also high (17\%). According to estimates, by 2015 the problem of being overweight will have affected $33 \%$ of adult Americans, and obesity will be a hindrance for nearly half of the U.S. population (42\%) (European Nutrition and Health Report 2009).

Also, the problem of excess weight and obesity is becoming increasingly important on the European continent (Berner-Trąbska et al. 2009). In the year 2009, 50\% of the European population was diagnosed with excess weight. Obesity concerned another 30\% of Europe's residents at the time. Obesity is a disease that occurs more frequently among women (22\% of inhabitants of Europe) than men (15\% of Europe's population). This problem deeply affects the residents of the UK, Greece and Spain. Among the countries of the European continent with the lowest percentage of people with excess weight and obesity are the Scandinavian countries (Denmark, Sweden, Norway) and France. Escess weight occurs in their case, among 35-41\% of men and among $20-24 \%$ of women while obesity is diagnosed among $7-9 \%$ of men and among 6-8\% of women (James 2009).

Over the last decade, escess weight and obesity have become a significant public health problem in Poland. The results of research conducted in 2000 by National Food and Nutrition Institute in Warsaw revealed that the problem of overweight affects as many as $41 \%$ of men and $28.7 \%$ women (WOBASZ 2005). It is worth emphasizing that the problem of body mass irregularity resulting from its excess affects more often women of reproductive age (10-15\%) and pregnant women (10-20\%) (Kanadys 2002).

\section{Fertility of women}

With the increasing industrialization of many countries and the development of civilization connected with it, the incidence of certain lifestyle diseases has increased significantly among their inhabitants (Hajduk 2012). The development of these diseases largely depends on such factors as lifestyle, environment and pollution, social factors, work performed and the conditions in which it takes place, the availability and level of health care and genetic factors. These factors also affect varying degrees of female fertility and its disorders.

Fertility is defined as the ability to conceive, or fertilization of the ovum and its proper implantation. It is an extremely complex phenomenon, which is subject to various processes both internal as well as external. Female fertility disorders and infertility among women represent a growing problem in many highly developed as well as developing countries. The scale of the problem made the WHO (World Health Organization) already in the 1980 's recognize infertility as a social disease, which, according to WHO's estimates, affects $13-15 \%$ of couples in reproductive age.

In contrast, the results that were obtained during the studies of Boivin et al. in 2007, showed that infertility occurs in about $9 \%$ of couples in reproductive age. In highly industrialized countries, the incidence of this phenomenon ranges from $3.5 \%$ to $16.7 \%$ of couples, while in developing countries, the incidence of infertility ranges from $6.9 \%$ to $9.3 \%$ of couples in reproductive age. According to other researchers, this phenomenon affects about $16 \%$ of couples (Hajduk 2012).

Unfortunately, the precise size of infertility phenomenon is impossible to determine. This is due not only to the fact that some couples struggling with this problem are not aware of it, but also due to the fact that some couples who have trouble with conception for all sorts of reasons do not report it to specialists.

Experts more and more frequently emphasize the link between lifestyle and nutrition and fertility, especially among women.

\section{The impact of obesity on reproductive capabilities of women}

The main reason for the body mass irregularity is an oversupply of energy exceeding the body's demand. This excess energy, if not used by the body to meet its current energy needs is deposited in the body as fat. Along with the increase in adipose tissue the person develops excess weight and obesity.

According to researchers, obesity poses a significant threat to the proper functioning of the reproductive processes of women as well as men (Fitzsimons, Modder 2010). The relationship between excess body weight and regularity of reproductive processes is noted mostly among young women (Hofny et al. 2010).

Excessive body weight occupies a very important place not only in the onset of lifestyle diseases, but also in the development of reproductive dysfunction. The researchers emphasize that abdominal obesity has a particularly adverse effect on women's fertility disorders (Greer et al. 2009). This is due to the fact that the adipose tissue is not only a kind of "reservoir" of energy. It is also a very active endocrine organ. Synthesis of estrogen takes place in it. A large amount of fat in the organism elongates its exposure to estrogen released by the adipose tissue. In addition, obesity leads to the development of the menstrual cycle disorders, more frequent occurrence of anovulatory cycles than it is with women of normal body mass, lower reproductive potential and the increase in the risk of miscarriage (Sarfati et al. 2010; Demissie, Milewicz 2003). 
Reduced fertility associated with excessive weight gain is also associated with impaired secretion and action of hormones. This disorder refers mainly to leptin, resistin, ghrelin and adiponectin. Hormonal disorders lead to disturbances in the growth and maturation of the follicle, the implantation of the fertilized ovum and embryo development (Moschos et al. 2002).

Many times a relationship between BMI and the possibility of becoming pregnant in a group of young women treated for infertility was shown. Patients with a BMI in excess of the values specified for normal body weight were characterized by a lower concentration of circulating Sex Hormone Binding Globulin (SHBG). High BMI was also correlated with an increased estradiol fraction circulating in blood of these women (Demissie, Milewicz 2003).

The researchers also emphasize the important relationship between BMI and the growth hormone secretion (Iranmanesh 1991). The higher the value of the patient's BMI, the lower rigor of the growth hormone is recorded. The researchers also noted that with the increase in BMI of $1 \mathrm{~kg} / \mathrm{m}^{2} 6 \%$ reduction in the secretion of this hormone is recorded. It should be emphasized that growth hormone plays a vital role in the whole process of procreation. It is in fact responsible for the correct and proper action and secretion of sex hormones, which in turn are responsible for the production and maturation of both sperm and ova.

In the opinion of Rich - Edwards et al (2002) the relationship between BMI and prolonged inability to become pregnant in the group of women diagnosed with infertility is clear. They attribute the existence of this relationship to the previously characterized hormonal changes which consequently lead to ovulation disorders. The results of their observations showed that ovulation disorders occur in $25 \%$ of women whose BMI was equal to or exceeded $25 \mathrm{~kg} / \mathrm{m}^{2}$.

There have been reports (Wickiewicz, Zimmer 2008), according to which the main cause of infertility among women with excess body weight is believed to be in the aforementioned insulin resistance and hyperinsulinemia. According to the researchers, they are responsible for hyperandrogenemia and stimulating the ovaries to produce ovarian androgens. Prolactinaemia, which is strictly associated with obesity, also, according to the researchers, is the cause of the ovulation disorders occurrence.

The results of research conducted by Chavarro et al (2007) showed a relationship between the diet of young women and their fertility. They described the characteristics of the nutritional model, which in their opinion may have a significant impact on reducing the infertility risk which is a consequence of ovulation disorders. The results they received allowed us to determine that the appropriate eating habits referred to as the "fertility diet" are associated with a reduced risk of infertility in $69 \%$ of patients undergoing the study in which they were proposed to alter eating habits.

Increasingly the impact of insulin sensitivity becomes highlighted which very often is closely related to body weight and the impact the diet has on fertility of young women (Kitabchi 2005). Insulin resistance resulting from excessive weight and poor diet leads to ovulation disorders, which in turn hinders fertilization. Therefore, according to experts a change in eating habits, diet supplementation in the micro and macroelements and the reduction or weight control can have a positive impact on the fertility of young women.

It should be noted, however, that excess weight and obesity are not factors lowering the fertility of women in a sustainable manner. Research results carried out Elnashar and Badawy (2011) have shown that already 5\% weight loss in relation to the initial value contributes to a slow standardization of the menstrual cycle. Such a decrease in body weight with some patients treated for infertility also contributed to reduction in the incidence of anovulatory cycles. This means that women suffering from excess weight or obesity who are planning to raise their own family or expanding the already existing one, through a change for a lighter, less caloric diet and regular physical activity can fulfill their dream.

Both obesity and infertility are a growing social problem. Therefore, the international actions should concentrated on expanding information about these disease and popularizing them. There is also need to preventing and effectively treating obesity and infertility.

\section{References:}

1. Badawy A., Elnashar A. (2011), Treatment options for polycystic ovary syndrome. Int. J. Womens Health; 3: 25-35.

2. Bebelska K.P., Ehmke vel Emczyńska E., Gmoch-Gajzlerska E. (2011), Otyłość jako czynnik zaburzający procesy rozrodcze, Nowiny Lekarskie; 80, 6, 499-507.

3. Berner-Trąbska M., Kowalska-Koprek U., Karowicz-Bilińska A. et al. (2009), Wpływ nadwagi lub otyłości u ciężarnych na przebieg ciq̨ży i okresu okołoporodowego z uwzględnieniem stanu urodzeniowego noworodka w oparciu o materiał kliniczny. Ginekol. Pol., 80, 845-850. 
4. Boivin J., Bunting L., Collins J.A. et al. (2007), International estimates of infertility prevalence and treatmentseeking: potential need and demand for infertility medical care. Hum. Reprod.; 22: 1506-1512.

5. Chavarro J.E., Rich-Edwards J.W., Rosner B.A. et al. (2007), Diet and lifestyle in the prevention of ovulatory disorder infertility. Obstet. Gynecol.; 110: 1050-1058.

6. Demissie M., Milewicz A. (2003), Zaburzenia hormonalne w otyłości. Diabetol. Prakt.; 3: 207-209.

7. Doak C.M. et al. (2012), Age standardization in mapping adult overweight and obesity trends in the WHO European Region. Obes Rev 13(2):174-191.

8. Fitzsimons K.J. Modder J. (2010), Setting maternity care standards for women with obesity in pregnancy. Semin. Fetal Neonatal Med., 15, 100-107.

9. Greer I.A., Walters B.N.J., Nelson-Piercy C. (2009), Otyłość. Wydawnictwo Elsevier Urban and Partner, Wrocław, 111-115.

10. Hajduk M. (2012), Wpływ masy ciała na płodność kobiet, Endokrynologia, Otyłość i Zaburzenia Przemiany Materii, tom 8, nr 3, s. 93-97.

11. Health and life style idicators in the European Union (2009), European Nutrition and Health Report 2009. Forum Nutr., Basel, Krager, 62, 157-201.

12. Hofny E.R.M., Ali M.E., Abdel-Hafez H.Z. et al. (2010), Semen parameters and hormonal profile in obese fertile and infertile males. Fertil. Steril., 94, 2, 581-584.

13. Iranmanesh A., Lizarralde G., Veldhuis J.D. (1991), Age and relative adiposity are specific negative determinants of the frequency and amplitude of growth hormone (GH) secretory bursts and the half-life of endogenous GH in healthy men. J. Clin. Endcocrinol. Metab.; 73: 1081-108.

14. James W.P. (2008), The epidemiology of obesity the size of the problem. J. Intern. Med. 263: 336-352.

15. Jarvie E., Ramsay J.E. (2010), Obstetric management of obesity in pregnancy. Semin. Fetal Neonatal Med., 15, 83-88.

16. Kanadys W.M., Leszczyńska-Gorzelak B. Mierzyński R. et al. (2002), Kliniczne aspekty otyłości w ciąży. Kliniczna Perinatologia i Ginekologia. Ośrodek Wydawnictw Naukowych, Poznań, 36, 145-151.

17. Kitabchi A.E., Temprosa M., Knowler W.C. et al. (2005), Role of insulin secretion and sensitivity in the evolution of type 2 diabetes in the diabetes prevention program: effects of lifestyle intervention and metformin. Diabetes; 54: 2404-2414.

18. Kłosiewicz-Latoszek R. (2010), Otyłość jako problem społeczny, zdrowotny i leczniczy. Probl. Hig., 91, 3, 339-343.

19. Moschos S., Chan J.L., Mantzoros C.S. (2002), Leptin and reproduction: a review. Fertil. Steril.; 77: 433-444.

20. Pupek-Musialik D., Kujawska-Łuczak M., Bogdański P. (2008), Otyłość i nadwaga - epidemia XXI wieku. Przew. Lek., 1, 117-123.

21. Rich-Edwards J.W., Spiegelman D., Garland M. (2002), Physical activity, body mass index, and ovulatory disorder infertility, Epidemiology; 13: 184-190.

22. Sarfati J., Young J., Christin-Maitre S. (2010), Obesity and female reproduction. Ann. Endocrinol.; 71: 49-53.

23. Wang Y., Beydoum M.A. (2007), The obesity epidemic in the United States - gender, age, socioeconomic racial/ ethnic and geographic characteristics: a systematic review and metaregression analysis. Epidemiol. Rev., 29, 6-28.

24. Wickiewicz D., Zimmer M. (2008), Otyłość a problem niepłodności u kobiet, Perinatologia, Neonatologia i Ginekologia, tom 1, zeszyt 2, 138-140.

25. Wieloośrodkowe Ogólnopolskie Badanie Stanu Zdrowia Ludności (2005), Program WOBASZ. Wydawnictwo Instytut Kardiologii, Warszawa, 90, 1-128.

Submitted: 05.05.2014

Accepted: 01.07.2014 